\title{
Human Capital Disclosure Practices: Do Performance and Budget Controlling Matter? (Evidence from Indonesian Local Governments)
}

\author{
Henny Murtini ${ }^{1}$, Djoko Suhardjanto ${ }^{2}$, Agung Nur Probohudono ${ }^{3}$, Djuminah $^{4}$ \\ \{hennymurtini@mail.unnes.ac.id $\left.{ }^{1}\right\}$ \\ Universitas Sebelas Maret, Indonesia ${ }^{1,2,3,4}$ \\ Universitas Negeri Semarang, Indonesia ${ }^{1}$
}

\begin{abstract}
This study aims to explore the effect of performance and budgeting control on human capital disclosure in Indonesian Local government in accordance with institutional theory. The reason for doing this study is the big budget allocation for employee expenditure in Indonesian local government and the existence of a Law on State Civil Apparatus but the lack of human capital disclosure in local government financial statement. It is a study on 140 local governments with cluster sampling and the hypothesis was proved by multiple regressions. The results showed that there was an effect of performance on human capital disclosure, while the budget controlling was not significant. Further statistical tests show there are differences in the local governments performance which located at Java Island and outside of Java. Future studies can also try to test the disclosure of human capital using only the four items index which widely expressed by local governments in Indonesia. There are about employee pay and benefits, employee awards, pension/old age insurance, and employee protection.
\end{abstract}

Keywords: Human Capital Disclosure, Performance, Budget Controlling, Institutional Theory

\section{Introduction}

Human capital disclosure is very important to overcome organizational, community and environmental problems. This is in accordance with the perspective of institutional theory. Previous study by DiMaggio \& Powell [1] and Scott [2] which is useful to increase transparency and disclosure can also strategically improve the alignment between goals and norms of the organization with community norms, facilitate the sustainability of the organizational operations in order to improve the reputation of the company and goodwill. Abeysekera [3] states that companies use disclosure to reduce tensions between organizations and stakeholders and based on Dillard, Rigsby \& Goodman [4] which states that organizations express voluntarily because of the strength or pressure exerted on the organization to resemble other units in dealing with the same environmental conditions. Dagilienė \& Nedzinskienė [5] stated that if companies tend to express one of the non-economic aspects voluntarily in their report, the company tends to reveal more about other non-economic problems in the perspective of institutional theory.

Burke, Noblet \& Cooper [6] stated that the strategy of managing human resources (HR) has an important role in ensuring public institutions provide services to the public with high standards of service consistently. Disclosure of human capital in financial statements is needed 
by stakeholders in making decisions for both companies and local governments. This is consistent with the study of Kansal \& Joshi [7] which found that there is no difference between the average disclosure of human capital from one industry to another and the disclosure practices of private companies and the public sector. The reality is that local governments have not shown uniformity (isomorphic) according to institutional theory in terms of human capital disclosure in local government financial statement. The followers of institutional theory states that organizations adapt isomorphic processes in the form of acceptance of values, norms, regulations, and others.

Human capital problems often occur in every organization. These problems certainly cause various decisions making and the achievement of organizational goals and even accountability and also transparency become questionable [8]. The problem with local governments related to human capital disclosure is the existence of high employee (related to human capital) expenditure budget. The personnel expenditure budget for paying the salaries of central and regional civil servants in 2017 is 495.7 trillion rupiah [9]. The employee expenditure budget for paying the salaries of central and regional civil servants is high because a quarter of the budget for the budget and the average increase to $22 \%$ per year.

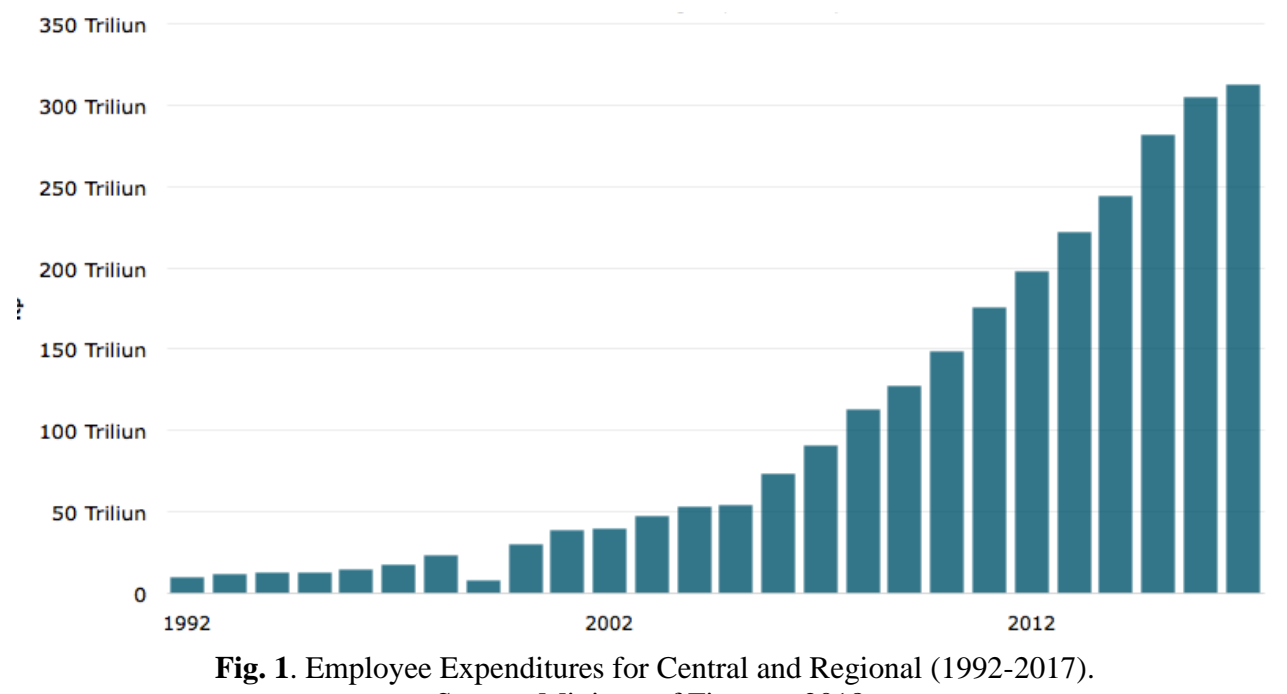

Source: Ministry of Finance, 2018.

Salaries of civil servants (PNS) have been budgeted in a quite big number by the government. In 2017 state budget (APBN), according to Kemenkeu [10], employee expenditure for salary reached Rp 343.3 trillion and goods expenditure was Rp 296.6 trillion from a total of Rp 1.13 quadrillion (thousand trillion). Employee expenditure covers 26.1 percent of the total central government budget, or about a quarter of the budget is used to pay salaries and fringe benefits of bureaucrats [11]. Expenditures for central and regional government employees have increased every year (Fig. 1).

In the 2016 APBD, 131 districts had a ratio of employee expenditure and fringe benefits to the total state budget reaching above 50 percent. So, most of the state budget is only for employee expenditure [12]. Based on data from the Directorate General of Fiscal Balance, the average portion of employee expenditure in the 2015 APBD, both provincial and district/city 
up to 40 percent. The allocation of employee expenditure at the district/city government level was recorded at an average of 46 percent.

Several studies on the level of disclosure to local governments in Indonesia also show inconsistencies. The inconsistency can be seen from the results of several studies. First, study by Suhardjanto \& Yulianingtyas [13] show the average value of mandatory disclosures in the regional government balance sheet shows 10.49 or 30.85 percent of 100 samples. Second, study by Setyowati [14]. the average disclosure rate of 314 local governments in 2014 showed 64 percent. Third, the level of disclosure of provincial government in Indonesia from 2006 to 2009 showed an upward trend [15]. Fourth, the average level of human rights disclosure in Indonesia is around $7 \%$ lower than in developed countries [16].

Similar to studies on human capital disclosure in go public companies, human capital disclosure is also very important in the government. The importance of disclosing human capital in each sector is certainly different. This is consistent with the results of a study by Kansal \& Joshi [7] which found that accountability in terms of human resource reporting in the public is higher than the private sector. Disclosure of human capital has not been regulated explicitly and specifically in Government Regulation Number 71 of 2010 concerning Government Accounting Standards (SAP), Law of the Republic of Indonesia No. 5 of 2014 concerning State Civil Apparatus (ASN) shows that ASN has the right to receive: salary, benefits, and facilities; paid leave; pension insurance and old age insurance; protection; and competency development, and Study Number 14 of International Public Sector Accounting Standards (IPSAS) which is published by the IPSAS Board (2011). Even though there is a statement that the information presented in accrual-based accounting in financial statement make it possible for stakeholders.

Three isomorphic components only the coercive component (measured by the number of members of parliament) has a significant influence on the level of disclosure [17][18]. It proves that in Indonesia, coercive pressure is still needed to increase transparency [19]. This is consistent with the argument of Graham \& Woods [20] that coercive pressure is suitable for developing countries. Arifin et al. [17][18] tested three isomorphic components with variables of the number of DPRD, the location of local government by distinguishing Java or Outside Java, the proportion of opposition parties. A study by Iliya Nyahas et al. [21] state that coercive and normative isomorphic mechanisms are positively related to voluntary disclosure, whereas mimetic mechanisms are not. Study by Iliya Nyahas et al. [21] organizational culture partly mediates the relationship between isomorphic influences and voluntary disclosure practices of registered companies in Nigeria. This is in accordance with social processes with the existence of isomorphic forces such as coercive, normative and mimetic clearly carried out by the external environment, so that public entities can directly adopt integrated report.

Tagesson et al. [22] show that internet-based social disclosure is related to company size, profitability, ownership and industry in companies registered in Sweden. Ali, Frynas \& Mahmood [23] find that company characteristics such as company size, industrial sector, profitability, and corporate governance mechanisms drive the CSR reporting agenda. In addition, political, social, and cultural factors influence the CSR disclosure agenda. Sahari \& Hamzah [24] and Yau, Chun \& Balaraman [25] found that profitability had no effect on human rights disclosure. Profitability is usually used to measure financial performance. Lajili \& Zéghal [26] found a positive and significant relationship between disclosure of labor costs and the market value of equity. Financial performance has various measurements. So, financial performance is positively related to human capital disclosure.

A study by Toorchi, Asiaei \& Dehghan [27] implies that companies with a high level of intellectual capital have sophisticated accounting systems and management controls. The relationship between the internal control system (including budgeting control) and the 
disclosure of human capital (intellectual capital) was also carried out by Möller, Gamerschlag \& Guenther [28]. The internal control system is good, so reporting to the outside parties (including disclosure) is also good. Thus, budgetary control also affects the disclosure of human capital.

Capital innovation indirectly affects disclosure if measured by the cost of ownership information and in other organizations it is often called as cost of software (investment). So, if the intensity of research and development is high then it affects disclosure. It is also in accordance to a study by Wright [29] which states that capital innovation has a positive effect on government policy. This study identifies the effect of performance and budget controlling on human capital disclosure. This study compiles the human capital disclosure index and uses institutional theory in identifying the determinants of human capital disclosure in local governments in Indonesia which make it different from other studies.

\section{Methods}

The type of this study is a quantitative study, which use secondary data obtained from the State Audit Board (BPK) in Jakarta, the annual report of the regional government in Indonesia in 2016. The population in this study is 513 Local Government in Indonesia. The analysis unit of this study is the organization so that each city or Regency This study analyzes the annual financial statements from 2016 because that year shows the period after Presidential decree No. 71 of 2010 concerning Government Accounting Standards, about the implementation of accrual basis reports. This study used proportional sampling technique. This financial statement data was obtained from a data base (BPK) which is published in the form of CD in February 2017.

The dependent variable of this study is human capital disclosure (HCD). Human Capital Disclosures are words or sentences about human capital disclosed by organizations in financial statements [3][30]. Thus, this study refers to the definition of human capital disclosure that was used Abeysekera [3][30], because it is more suitable with the definition of the civil service (ASN) and employees in the financial statements of local governments in Indonesia. This study uses index analysis to measure human capital disclosure which is developed based on the framework of Beattie \& Thomson [31], Pisano, Lepore \& Lamboglia [32], Bontis [33], Guthrie \& Petty [34], Guthrie et al. [34], Guthrie, Petty \& Ricceri [35], Adelowotan [36] and others (attached). The steps to prepare the index as follows

a. Mapping theory and previous study on human capital disclosure. The results found 211 indicators of human capital disclosure.

b. Those indicators are arranged in a questionnaire and distributed (surveys) to several stakeholders. The stakeholders are auditors (BPK and BPKP), Actors (Local Government), Academics (researchers), and policy makers (MOHA).

c. The survey results are identified by and carried out as a basis for interviews to see their consistency. After surveys and interviews related to 211 indicators were categorized using factor analysis, there are obtained 51 items.

d. Fourteen keywords were obtained from the categorization of indicators. The next process is analyzing another factor based on the keywords adopted in the Law on State Civil Apparatus which amounted to 14 (fourteen) keywords. The keywords that were used to identify human capital disclosure including the preparation and determination of needs, procurement, rank and position, career development, promotion, transfer, performance appraisal, payroll and benefits, awards, discipline, dismissal, retirement guarantees and 
guarantees old age, as well as protection. Each keyword if disclosed is given a score of 1 (one).

e. This study also tested the validity and reliability testing with the intercoder by experts in public accounting.

Financial performance in this study was defined as a performance measure that uses financial indicators. It was developed from the definition of performance according to Gimzauskiene \& Kloviene [38], which is a feature of achievement level of the implementation of an activity or program and policy in realizing the goals, objectives, mission and vision of the organization as outlined in the strategic planning of an organization. This study uses the performance score of government administration in the Decree of the Minister of Home Affairs No. 100-53 of 2018 concerning the Ranking and Status of National Government Implementation Performance. The performance score of the government administration is the ranking and status of the performance of local government administration in 2018.

Budget controlling is the effectiveness of budget controlling which includes planning, feedback and control interactions that are important to improve government performance in the implementation of performance-based budgeting. Thus, budget controlling is measured by the amount of the revenue budget target minus the realization of the revenue budget minus the amount of the expenditure/expenditure budget target after deducting the realization of the government expenditure/expenditure.

The control variables in this study are capital innovation and size (total assets). Capital innovation shows the creation of something new, which has been studied for decades [39][40]. Capital innovation in this study is measured by the intensity of capital innovation that is the cost of research and development divided by total assets. Size is a measure of local government that can be indicated by the number of assets owned. Size in this study was measured by the natural logarithm of total assets.

\section{Results and Discussion}

\subsection{Descriptive Results}

Table 1. Descriptive Statistics of the Dependent, Independent and Control Variables

\begin{tabular}{llllll}
\hline Variable & Obs & Mean & Std. Dev. & Min & Max \\
\hline HCD & 140 & 0,287 & 0,027 & 0,142 & 0,5 \\
KK & 140 & $31.050,79$ & $3.194,328$ & 13.619 & 35.926 \\
PP & 140 & 0,067 & 0,047 & $-0,018$ & 0,244 \\
INOV & 140 & 1,920 & 5,453 & 0,019 & 54,965 \\
Size & 140 & 28,686 & 0,686 & 27,471 & 31,272 \\
\hline
\end{tabular}

Source: Secondary processed data, 2018.

The maximum human capital disclosure value is owned by the Regional Government of Puncak Jaya Regency. This can be interpreted that the Puncak Jaya Government in 2016 has a high level of human capital disclosure. The minimum value of the variable level of human capital disclosure owned by the Regional Government of Toba Samosir Regency, it means that the Regional Government of Toba Samosir Regency in 2016 has a low level of human capital disclosure. The average value is greater than the standard deviation value, so that it can be interpreted as the spread of variable data on the human capital disclosure level to spread heterogeneously. 
The minimum performance value was owned by the Puncak Jaya Regency in 2016, so it can be interpreted that the Puncak Jaya Regency in 2016 had a low performance score or the performance of the local government as measured by a relatively low performance score. The maximum value of the local government performance variable from this study was 35,926 . This value is owned by the local government in Sidoarjo which means that in 2016. Sidoarjo has a high local government performance. The resulting average value is greater than the standard deviation value, so it can be interpreted as a variable spread of regional government performance data distributed heterogeneously.

The minimum budget controlling value is owned by the local government of Toba Samosir in 2016, so it can be interpreted that the Toba Samosir has low budget controlling and the local government is considered low in managing its budget as measured by the acquisition of surpluses/deficits. The maximum value of the budgeting control variable which is owned by the North Lombok Regency Government in 2016, which means that the local government of North Lombok in 2016 has a high level of budget controlling or the local government is considered as good in managing its budget so that the surplus/deficit is also high. The average value is greater than the standard deviation value, so that it can be interpreted as the data on budgetary control variable spread heterogeneously.

\subsection{Regression Analysis}

Table 2. Results of Multiple Linear Regression

\begin{tabular}{lllc}
\hline Variable & Coefficient & $\mathbf{t}$ & $\mathbf{P}>[\mathbf{t}]$ \\
\hline -cons & 0,199 & 2,03 & 0,045 \\
$\mathrm{kk}$ & $-0,000$ & $-3,88$ & 0,000 \\
$\mathrm{pp}$ & 0,005 & 0,10 & 0,922 \\
inov & 0,001 & 1,13 & 0,258 \\
size & 0,006 & 1,73 & 0,085 \\
Obs $=140$, Fhitung $=4,26$, Sig $\mathrm{F}=0,002, \mathrm{R}^{2}=0,112$, Adjusted \\
$R^{2=0,086}$
\end{tabular}

Source: Secondary processed data, 2018.

Table 2 shows the coefficient of determination of the adjusted R square of 0.086 or $8.6 \%$. This shows that $8.6 \%$. of human capital disclosure variable in local governments explained by the independent variables in this study which is the performance, and budgeting control. The remaining $91.4 \%$ is influenced by other variables which is not included in this study model. Table 2 shows the significant value in the F significant test showing the number of 0.002 , that is $0.002<0.05$ so it can be concluded that the independent variables in this study affect the dependent variable.

$$
\mathrm{HCD}=0,991-0,001 \mathrm{P}+0,004 \mathrm{BC}+0,001 \mathrm{ICI}+0,006 \mathrm{SIZE}+\varepsilon
$$

\subsection{Effect of Performance on Disclosure of Human Capital}

Performance variables obtained by $\mathrm{t}$ count of -3.88 a significant level of 0,000 $(0,000<0.05)$. These results indicate that the performance has a significant negative effect on human capital disclosure in local governments, so the first hypothesis is not rejected. Higher performance led to lower human capital disclosure level in Indonesian local governments in and 
lower performance of government implementation led to higher level of human capital disclosure.

The results of this study emphasize that the relationship between performance and human capital disclosure is still diverse. The results of this study are in line with Abdulla \& Mamun [41] and Souza et al. [42] who found a significant relationship with profitability of the company (one of the indicator is performance and the reporting of human capital. The results of this study differ from the studies of Alam \& Deb [43] and Eddine et al. [44] which show that there is a positive relationship between performance and human capital disclosure. This study shows a negative influence between performance and human capital disclosure. Other research results that show that according to Melloni [45] which find that positive intellectual capital disclosure tone is associated with decreased performance, greater size, and level of intangibles that support the use of intellectual capital disclosure as impression management. While the results of Wang \& Chang [46] also found different results that there is no effect of human capital on performance, but human capital affects performance through innovative capital and process capital. This study shows that most local governments disclose human capital regarding employee payroll and benefits, employee awards, pension/old age insurance, and employee protection. This indicates that the regional government suspicion only discloses that it is closely related to monetary matters. Items related to soft skill or attitudes are rarely disclosed. The research findings differ from the findings of Khan \& Khan [47] which shows the most frequently disclosed human capital items are information about employee training, number of employees, career development, opportunities provided by the company, and employee recruitment policies.

\subsection{Effect of Budget Controlling on Human Capital Disclosure}

Budget controlling variable obtained t count of 0.10 significant level of 0.922 (0.922> $0.05)$. The second hypothesis $\left(\mathrm{H}_{2}\right)$ which states budget controlling affects human capital disclosure in Indonesian local governments is rejected. The results of this study do not support a study by Toorchi et al. [27] and Möller et al. [28] which does not support study by which states there is a relationship between budget controlling (internal control system) and the disclosure of human capital. The internal control system is good, so reporting to outside parties (including disclosure) is also good. So, the results of this study have not been able to prove that budget controlling also affects the disclosure of human capital. The results of this study are not in accordance with institutional theory. Local government management is not encouraged to disclose information to reduce the risk of negative views from the public.

\subsection{Additional Testing}

The value of Chi-Squared of these two variables is 48,247 and 26,070 with DF2, then pvalue of Kruskall Wallis test is 0,000 which is less than the critical limit of 0.05 so it can be concluded that the treatment gives a significant difference mean in the value of the variable or which means $\mathrm{H} 1$ is accepted and Ho is declined, since the H1 is accepted then continued with Post Hoc Test or Further Test. As discussed earlier, Post Hoc after Kruskall Wallis can be done with the Mann Whitney U Test and is often called the Wilcoxon Signed Rank Test.

The analysis result shows that 117 local governments outside of Java, which had capital innovation sum rank of 7,831 lower than local governments in Java. Table 3 show that 117 local governments outside of Java, which had a sum rank of performance of 9,870, higher than local governments in Java, while 23 local governments outside of Java, which had a capital innovation sum rank value of 1,979, higher than local governments in Java. 
Table 3. The Result of Kruskal Wallis Test

\begin{tabular}{|c|c|c|c|c|c|c|c|c|}
\hline \multirow[b]{2}{*}{ Variable } & \multicolumn{4}{|c|}{ City/Regency } & \multicolumn{4}{|c|}{$\begin{array}{c}\text { Local Government in Java or Outside } \\
\text { Java }\end{array}$} \\
\hline & $\begin{array}{l}\text { Chi- } \\
\text { Squared }\end{array}$ & $\begin{array}{c}\mathrm{P} \\
\text { value }\end{array}$ & $\begin{array}{c}\text { Chi- } \\
\text { Squared } \\
\text { Ties } \\
\end{array}$ & $\begin{array}{c}\mathrm{P} \\
\text { value }\end{array}$ & $\begin{array}{l}\text { Chi- } \\
\text { Squared }\end{array}$ & $\begin{array}{c}\mathrm{P} \\
\text { value }\end{array}$ & $\begin{array}{l}\text { Chi- } \\
\text { Squared } \\
\text { Ties }\end{array}$ & $\begin{array}{c}\mathrm{P} \\
\text { value }\end{array}$ \\
\hline hed & 0,010 & 0.921 & 0,068 & 0,793 & 0,162 & 0,687 & 0,132 & 0,287 \\
\hline $\mathrm{kk}$ & 0,229 & 0,633 & 0,229 & 0,633 & 48,247 & 0,000 & 48,247 & 0,000 \\
\hline $\mathrm{pp}$ & 5,365 & 0,205 & 5,365 & 0,205 & 0,797 & 0,372 & 0,797 & 0,372 \\
\hline inov & 0,535 & 0,464 & 0,535 & 0,464 & 26,070 & 0,000 & 26,070 & 0,000 \\
\hline
\end{tabular}

Source: Secondary processed data, 2018.

Based on the results of the calculations Wilcoxon Signed Rank Test according to table 4, the $\mathrm{Z}$ value obtained for the variable performance of 10.265 and capital innovation of $-6,149$ with $p$ values each of 0,000 less than the critical limit of the study 0.05 so that hypothesis $(\mathrm{H} 1)$ is accepted or its mean there are differences in performance and capital innovation between local governments which located on Java and local governments located outside Java. A further non-parametric test is testing the differences of each variable in this study compared to the local governments (regencies and cities) as well as local governments which are located in Java and outside of Java. The results of the statistical analysis show that only capital performance and innovation differ (mean) between local governments in Java and Outside Java. This indicates that the performance and capital innovation of local government in Java whose government is close to technological and information development and close to the center of the capital city are thought to be more advanced than local governments outside Java.

\section{Conclusion}

The results of the study indicate that performance affects human capital disclosure in Indonesian local governments. The influence is seen from the performance of the implementation of increasing human capital disclosure; so that the $\mathrm{H}_{1}$ which states the performance affects human capital disclosure is not rejected, while budgeting control variables do not affect human capital disclosure. It shows that higher budgeting control does not increase human capital disclosure, so the second hypothesis $\left(\mathrm{H}_{2}\right)$ which states that budgeting control affects the disclosure of human capital is rejected.

The results of this study produce a human capital disclosure index that can be a measuring tool about human capital that reflects more reliable and quality financial statement so as to reduce the risk of trust in financial statements that are wrong or less accountable. Local government financial statement should contain or disclose human capital because it is in accordance with the mandate of the Law on State Civil Apparatus and most of the budgetary allocation to local governments in Indonesia is related to human resources. The implementation can be carried out by local governments in accordance with institutional theory in isomorphism coercive, normative and mimetic. Therefore, this research is able to provide input on the policy to determined regulations regarding human capital disclosure and performance.

In practice, most local governments only disclose human capital related to employee payroll and benefits, employee awards, pension/old age insurance, and employee protection. The financial statement of local government that has been regulated in presidential decree No. 71 of 2010 has not been able to regulate generally what is in the Law on Civil Service. In 
particular there is a disclosure related to human resources or the state civil apparatus. Since it is voluntary, human capital disclosure of in Indonesian local government is still very minimal. The diversity of reporting format document in local government (for example pdf not picture/jpeg) shows weak regulation in technical point of view.

Further study is recommended to reexamine the research variables which prove other variables that influence human capital disclosure in Indonesian local governments. Future studies can also try to test the disclosure of human capital using only the four items index which widely expressed by local governments in Indonesia, it is about employee pay and benefits, employee awards, pension/old age insurance, and employee protection. Based on additional analysis also raises the implication that future study can explore the relationship of capital innovation with performance and budgeting control. For capital innovation the next study can try to use other measurements, for example the development of fixed asset investment, growth of fixed assets, and others.

\section{References}

[1] P. J. DiMaggio and W. W. Powell, "Institutional Isomorphism and Collective Rationality in Organizational Fields," Am. Sociol. Rev., vol. 48, no. 2, pp. 147-160, 1983.

[2] W. R. Scott, "The Adolescence of Theory Institutional," Adm. Sci. Q., vol. 32, no. 4, pp. 493 $511,1987$.

[3] I. Abeysekera, "Motivations behind human capital disclosure in annual reports," Account. Forum, vol. 32, no. 1, pp. 16-29, 2008.

[4] J. F. Dillard, J. T. Rigsby, and C. Goodman, "The making and remaking of organization context: Duality and the institutionalization process," Accounting, Audit. Account. J., vol. 17, no. 4, pp. 506-542, 2004.

[5] L. Dagilienè and R. Nedzinskiené, "An institutional theory perspective on non-financial reporting: The developing Baltic context," J. Financ. Report. Account., vol. 16, no. 4, pp. 490521, 2018.

[6] R. Burke, A. Noblet, and C. Cooper, "The importance of human resource management in the public sector, future challenges and the relevance of the current collection," in Human Resource Management in the Public Sector, 2013, pp. 1-13.

[7] M. Kansal and M. Joshi, "Reporting human resources in annual reports," Asian Rev. Account., vol. 23, no. 3, pp. 256-274, 2015.

[8] Y. Ramírez-Córcoles and M. Manzaneque-Lizano, "The relevance of intellectual capital disclosure: Empirical evidence from Spanish universities," Knowl. Manag. Res. Pract., vol. 13, no. 1, pp. 31-44, 2015.

[9] Mulyani, "Berapa Belanja Pegawai di APBN 2017?," 2017.

[10] Kemenkeu, "Pemerintah Habiskan Hampir Rp 500 Triliun Buat Gaji PNS," 2017.

[11] Kemenkeu, "Belanja Pegawai Pemerintah Sepanjang 1992-2017 Mengalami Kenaikan 22 tahun," 2018.

[12] E. Simorangkir, "Sri Mulyani: Ada 131 Daerah yang Setengah-APBD Habis Buat Gaji PNS," 10 Mei 2017, 2017.

[13] D. Suhardjanto and R. R. Yulianingtyas, "Pengaruh Karakteristik Pemerintah Daerah terhadap Kepatuhan Pengungkapan Wajib dalam Laporan Keuangan Pemerintah Daerah (Studi Empiris pada Kabupaten / Kota di Indonesia)," J. Akunt. Audit., vol. 8, no. 1, pp. 30-42, 2011.

[14] L. Setyowati, "Determinan yang Mempengaruhi Pengungkapan Laporan Keuangan Pemerintah Daerah," Esensi, vol. 6, no. 1, pp. 45-62, 2016.

[15] A. Z. Hilmi and D. Martani, "Analisis Faktor-Faktor yang Mempengaruhi Tingkat Pengungkapan Laporan Keuangan Pemerintah Provinsi,” Simp. Nas. Akunt. XV, pp. 1-26, 2012.

[16] A. N. Probohudono, Y. A. Sudibyo, A. Atmaji, and M. N. Kholid, "Human rights disclosure practices. Does ownership matter? (evidence from Indonesia)," Corp. Board Role, Duties 
Compos., vol. 11, no. 2, pp. 149-158, 2015.

[17] J. Arifin, G. Tower, and S. Porter, "Fiscal Policy Disclosure in Indonesia Local Governments," JAAI, vol. 17, no. 1, pp. 13-30, 2013.

[18] J. Arifin, G. Tower, and S. Porter, "Financial Reporting Compliance In Indonesian Local Governments: Mimetic Pressure Dominates," JAAI, vol. 19, no. 1, pp. 68-84, 2015.

[19] F. R. Cahaya, S. Porter, G. Tower, and A. Brown, "The Indonesian Government's coercive pressure on labour disclosures: Conflicting interests or government ambivalence?," Sustain. Accounting, Manag. Policy J., vol. 6, no. 4, pp. 475-497, 2015.

[20] D. Graham and N. Woods, "Making corporate self-regulation effective in developing countries," World Dev., vol. 34, no. 5 SPEC. ISS., pp. 868-883, 2006.

[21] S. Iliya Nyahas, J. C. Munene, L. Orobia, and T. Kigongo Kaawaase, "Isomorphic influences and voluntary disclosure: The mediating role of organizational culture," Cogent Bus. Manag., vol. 4, no. 1, pp. 1-18, 2017.

[22] T. Tagesson, V. Blank, P. Broberg, and S.-O. Collin, "What explains the extent and content of social disclosures on corporate websites?," Corp. Soc. Responsib. Environ. Manag., vol. 16, no. March, pp. 352-364, 2009.

[23] W. Ali, J. G. Frynas, and Z. Mahmood, "Determinants of Corporate Social Responsibility (CSR) Disclosure in Developed and Developing Countries: A Literature Review," Corp. Soc. Responsib. Environ. Manag., vol. 24, no. 4, pp. 273-294, 2017.

[24] S. Sahari and N. Hamzah, "the Impact of Corporate Characteristics on Human Rights Disclosure: Construction Companies in Malaysia," J. Hum. Cap. Dev., vol. 7, no. 1, pp. 49-64, 2014.

[25] F. S. Yau, L. S. Chun, and R. Balaraman, "Intellectual Capital Reporting and Corporate Characteristics of Public-Listed Companies in Malaysia," J. Financ. Report. Account., vol. 7 , no. 1, pp. 17-35, 2009.

[26] K. Lajili and D. Zéghal, "Labor cost voluntary disclosures and firm equity values: Is human capital information value-relevant?," J. Int. Accounting, Audit. Tax., vol. 14, no. 2, pp. 121-138, 2005.

[27] M. Toorchi, K. Asiaei, and M. Dehghan, "Intellectual Capital and Management Accounting Practices: Evidence from Iran," Procedia Econ. Financ., vol. 31, no. 15, pp. 775-788, 2015.

[28] K. Möller, R. Gamerschlag, and F. Guenther, "Determinants and effects of human capital reporting and controlling," Jounal Manag. Control, vol. 22, pp. 311-333, 2011.

[29] W. F. Wright, “Academic Instruction as a Determinant of Judgment Performance," vol. 19, pp. 247-259, 2007.

[30] I. Abeysekera, "Role of remuneration committee in narrative human capital disclosure," Account. Financ., vol. 52, pp. 1-23, 2011.

[31] V. Beattie and S. J. Thomson, "Lifting the lid on the use of content analysis to investigate intellectual capital disclosures," Account. Forum, vol. 31, no. 2, pp. 129-163, 2007.

[32] S. Pisano, L. Lepore, and R. Lamboglia, "Corporate disclosure of human capital via LinkedIn and ownership structure," J. Intellect. Cap., vol. 18, no. 1, pp. 102-127, 2017.

[33] N. Bontis, "Intellectual Capital Disclosure in Canadian Corporations," J. Hum. Resour. Costing Account., vol. 7, no. 1, pp. 1-26, 2002.

[34] J. Guthrie and R. Petty, "Intellectual capital: Australian annual reporting practices," J. Intellect. Cap., vol. 1, no. 3, pp. 241-251, 2000.

[35] J. Guthrie, R. Petty, K. Yongvanich, and F. Ricceri, "Using content analysis as a research method to inquire into intellectual capital reporting," J. Intellect. Cap., vol. 5, no. 2, pp. 282-293, 2004.

[36] J. Guthrie, R. Petty, and F. Ricceri, "The voluntary reporting of intellectual capital: Comparing evidence from Hong Kong and Australia," J. Intellect. Cap., vol. 7, no. 2, pp. 254-271, 2006.

[37] M. O. Adelowotan, "Human capital disclosure in corporate annual reports," 2013.

[38] E. Gimzauskiene and L. Kloviene, "Performance Measurement System: Towards an Institutional Theory," Eng. Econ., vol. 22, no. 4, pp. 338-344, 2011.

[39] R. M. Walker, F. Damanpour, and C. A. Devece, "Management innovation and organizational performance: The mediating effect of performance management," J. Public Adm. Res. Theory, vol. 21 , no. 2 , pp. $367-386,2011$. 
[40] M. N. Kotsemir and A. Abroskin, "Innovation Concepts and Typology - An Evolutionary Discussion," SSRN Electron. J., 2013.

[41] S. Abdulla and A. Mamun, "Human Resource Accounting (Hra) Disclosure of Bangladeshi Companies and Its Association With Corporate Characteristics," BRAC Univ. J., vol. 1, no. 1, pp. 35-43, 2009.

[42] G. H. C. Souza, L. A. F. Junior, U. C. T. Lagioia, and J. G. N. de Araujo, "Financial Performance and Information Disclosure on Human Resources: An Analysis of Companies in The IBrX - 100 Umbelina Cravo Teixeira Lagioia," J. Educ. Res. Account., vol. 22, no. 5, pp. 88-102, 2016.

[43] I. Alam and S. K. Deb, "Human Resource Accounting Disclosure (HRAD) In Bangladesh: Multifactor Regression Analysis - A Decisive Tool of Quality Assessment," Cost Manag., vol. 25, no. 2004, pp. 9-13, 2010.

[44] C. O. H. Eddine, S. N. Abdullah, F. A. Hamid, and D. M. Hossain, "The determinants of intellectual capital disclosure: A meta-analysis review," J. Asia Bus. Stud., vol. 9, no. 3, pp. 232 250, 2015.

[45] G. Melloni, "Intellectual capital disclosure in integrated reporting: An impression management analysis," J. Intellect. Cap., vol. 16, no. 3, pp. 661-680, 2015.

[46] W. Y. Wang and C. Chang, "Intellectual capital and performance in causal models. Evidence from the information technology industry in Taiwan," J. Intellect. Cap., vol. 6, no. 2, pp. 222236, 2005.

[47] H. Khan and R. Khan, "Human capital disclosure practices of top Bangladeshi companies," $J$. Hum. Resour. Costing Account., vol. 14, no. 4, pp. 329-349, 2010. 